\title{
REVIEW OF FACILITIES MANAGEMENT FUNCTIONS IN VALUE MANAGEMENT PRACTICES
}

\author{
Nordiana Mohd Isa ${ }^{1}$, Syahrul Nizam Kamaruzzaman ${ }^{1 *}$, Othman Mohamed ${ }^{2}$, \\ Mohamed Ali Berawi ${ }^{3}$ \\ ${ }^{1}$ Department of Building Surveying, Faculty of Built Environment, University of Malaya, 50603 Kuala \\ Lumpur, Malaysia \\ ${ }^{2}$ Department of Quantity Surveying, Faculty of Built Environment, University of Malaya, 50603 Kuala \\ Lumpur, Malaysia \\ ${ }^{3}$ Department of Civil Engineering, Faculty of Engineering, Universitas Indonesia, Kampus UI Depok, \\ Depok 16424, Indonesia
}

(Received: February 2017 / Revised: September 2017 / Accepted: October 2017)

\begin{abstract}
This paper identifies the functions of facilities management (FM) in value management (VM) studies in Malaysia. Most previous research in this area has discussed the history, evolution, knowledge, challenges, and contributions of FM in both the private and the public sectors, yet it is also essential to explore the benefits of FM involvement and the drawbacks of FM noninvolvement in VM studies during the pre-construction stage in Malaysia. This paper provides an overview the FM manager's roles in a VM workshop based on a review of literature collected and compiled from various publications. The study contributes to current knowledge by addressing the five elements of FM functions and their impacts on VM studies. The findings will enhance project, product, and service value by illustrating the importance of FM functions in a VM study.
\end{abstract}

Keywords: Facilities management; Malaysia; Pre-construction; Value management

\section{INTRODUCTION}

Facilities management (FM) and value management (VM) are relevant in Malaysia because buildings are used every day, and the country cannot afford to deliver mediocrity. Architects, engineers, designers, and tenants play major roles in determining the value of a building, as well as any potential to save time, money, or effort. According to Kamaruzzaman and Zawawi (2010), the term facilities management covers a wide range of services, including real estate management, contract management, change management, human resource management, financial management, and health and safety management. The term also covers building maintenance, utility supplies, and domestic services (e.g. cleaning and security).

Tladi (2012) remarked that "Buildings can last a very long time and it is better to design for efficiency and cost-effective operations and maintenance from the beginning" (p. 6). It is likely that the functions of FM offer certain advantages. Therefore, when a facility uses FM functions that relate to the elements of a VM study, the overall value of the facility will decline proportionately to the cost of building maintenance (Enoma, 2005). In addition, Xianhai (2013) stated that a lack of early FM engagement during the pre-construction stage may cause

\footnotetext{
*Corresponding author's email: syahrulnizam@um.edu.my, Tel: +603-7967-6833, Fax: +603-7967-5713 Permalink/DOI: https://doi.org/10.14716/ijtech.v8i5.865
} 
problems relating to the improper use of building materials and equipment.

Furthermore, such an oversight may result in every aspect of the building being more complex and expensive to repair when the building is completed. Without early FM involvement, there can be no feedback on proposed design elements. As a result, problems may be less defined and, thus, less likely to be solved during the early stages.

Problems can make facilities difficult and costly to control and maintain. However, rather than carrying out an analysis to identify design flaws, companies often blame the FM team. Therefore, in recent years, there has been an increasing amount of literature on the importance of FM involvement during the pre-construction phase of projects (Erdener, 2003; Tladi, 2012; Jawdeh, 2013; Wang et al., 2013). This literature has identified the important role of FM managers during the pre-construction phase, which involves the following aspects: (i) client satisfaction; (ii) energy efficiency; (iii) operation and maintenance; (iv) space management; and (v) sustainability.

Both FM and VM should be applied during the early phases of a project and throughout the whole life cycle of a building (Jensen, 2009). Therefore, the present paper aims to review the knowledge gaps concerning the importance of FM for design reviews (e.g. during the inception and conception stages prior to the approval stage). FM involvement in design reviews is important because maintenance costs increase relative to the improper maintainability of maintenance equipment. The literature review shows that both FM and VM should be integrated to allow designers to consider the various aspects of FM in their designs, as well as to enhance design support functions. However, few studies have addressed the topic of FM involvement in VM, especially in the Malaysian context. Therefore, this paper seeks to identify the importance of FM functions in VM studies in Malaysia.

\section{METHODS}

The aim of this study is to provide useful information pertinent to the functions of FM in a VM study on the pre-construction stage in Malaysia. The research seeks to establish a deeper understanding of FM functions relating to client satisfaction, energy efficiency, operation and maintenance, space management, and sustainability in the study of VM in Malaysia. The paper discusses the findings of a literature search as they relate to the functions of FM in VM practices.

\section{LITERATURE REVIEW}

A literature search was conducted to identify studies related to FM functions and VM studies. The review process involved searching for published studies from the ScienceDirect, Emerald, and Scopus databases using the keywords facilities management, Malaysia, pre-construction and value management. Related theses, conference proceedings, and review articles were also reviewed. The study excluded literature that was considered redundant. The study focused on studies on FM functions published between 1999 and 2016. The search identified seven constructs with 50 items important for identifying the functions of FM in VM practice. Descriptions of each of the constructs related to FM are presented in the next subchapter to illustrated the relationships between these constructions and the involvement of FM in VM studies during the pre-construction stage, as depicted in the literature.

\subsection{Client Satisfaction}

According to Jawdeh (2013), FM managers must coordinate with clients to acknowledge the requirements of users and proprietor businesses. The association between FM and society can influence the sharing of expertise pertinent to the various aspects of FM with both clients and designers. Jawdeh (2013) also maintained that the participation of FM managers is important in 
a VM study, particularly with respect to answering questions posed by designers. Previous studies have primarily dismissed the notion of significant designer interest in building performance at the occupancy stage (Way, 2006; Jawdeh, 2013).

In another study, Talib (2013) found that FM managers assist in the preparation of project specifications. Information extracted from prior projects and buildings should be assessed to develop design considerations for new facilities. To relate Post-Occupancy Evaluations (POEs) to workplace design, Preiser (2003) stated that POEs operate in accordance with facility design, which encompasses: (i) the high-quality influence of workplace design on an organization's desired outcomes; (ii) the contribution of workplace designs to cutting non-relevant costs and increasing revenues; and (iii) the impacts of workplace designs on improving human resource development.

FM managers can also use POEs to optimize building performance (Tladi, 2012). According to Yasin (2013), consumer needs are constantly demonstrated through service level agreement (SLAs). An in-house FM service provision dominates FM decision-making, which includes the development of FM, expenditures, and human resources (Yasin, 2013). Meanwhile, an outsourced FM is restricted to client SLAs. There is a difference between the "weightages" of the facilities performance evaluations supported by outsourced and in-house FM service provisions. Hence, it is important to acknowledge service inputs in the SLA at the earliest design stage (Koleoso et al., 2013; Yasin, 2013; Ikediashi, 2014).

\subsection{Energy Efficiency}

The world is currently facing a deterioration of natural resources, increasing utility costs, and global warming. Thus, stakeholders in the built environment are responsible for committing to sustainability efforts by developing facilities that require minimal resources to build, operate, and maintain (Tladi, 2012). By raising concerns at the design stage, FM managers can contribute to facility efficiency, or cost-effectiveness. In so doing, they can competently achieve their objectives and implement cost-effective design solutions that benefit buildings' entire life cycles (Enoma, 2005). Thus, there is a need for FM managers to check the appropriateness of utility services during the building design.

Tladi (2012) specified that FM managers must provide significant contributions to sustainability strategies that require few resources. They can accomplish this by assisting in the design of cost-effective facilities. Cloete (2002) and Tladi (2012) have made several attempts to show that water services must be easily accessible for regular service purposes and to avoid unpredictable incidents. Similarly, Lehrer (2001) suggested that the design of any water systems should focusing on ease and costs of operation and constant maintenance. For instance, to conserve water, an FM may recommend changing high-pressure flush toilets to low-pressure flush toilets.

Hartungi and Jiang (2012) discuss lighting efficiency, which can be considered to conserve energy and reduce costs. FM managers should also consider the energy efficiency of thermal factors. According to Atkin and Björk (2007) and Wan-Hamdan et al. (2011), the majority of organizations wish to provide comfortable working environments to enhance the productivity of employees and management, and thermal efficiency is one of the components of productiveness affected by environmental factors. Finally, Mcauley et al. (2015) created a client's brief that promotes better thermal efficiency, enhanced artificial lighting, improved acoustics, and the addition of a shop unit.

\subsection{Operations and Maintenance}

FM managers also play an important role in lowering maintenance costs (Enoma, 2005, Che'Mat \& Shah, 2006). Their research on the advantages of FM, particularly in hospitals and hotels, suggests that a large proportion of any given building supports facilities and the 
management of core activities. Likewise, Mustapa (2013) acknowledged that FM managers' authority relates to conceptual design. Kelly et al. (2005) and Mustapa (2013) recognized the three distinct levels of FM: (i) strategic FM, which is concerned with the direction of the FM function and includes setting objectives in response to the purpose of the FM function, carrying out long-term planning, and considering external requirements; (ii) tactical FM, which is concerned with making an FM organization function as a whole; and (iii) operational FM, which is concerned with day-to-day decisions in operating facilities.

Tladi (2012) suggested that FM managers should estimate the impacts on the cost of FM during the pre-construction stage. Since the delivery of a facility at the lowest possible cost is no longer paramount in the construction industry, it is vital to be aware of and to consider a facility's whole life cycle cost. Furthermore, in order to inspect permanently fixed elements, FM managers must focus on areas requiring constant maintenance (Enoma, 2005). The project team should develop resolutions to meet business needs throughout the lifetime of a facility and outline requirements for future facility maintenance. During the design stage, FM managers should propose an effective, yet cost-efficient facility and accomplish daily tasks concerning other ad hoc roles within the facility (Enoma, 2005).

A building's current conditions and ease of access both influence its maintenance costs. For example, a building that is poorly maintained and offers poor access for maintenance and cleaning purposes will have higher maintenance and cleaning costs. Moreover, buildings that are difficult to access may require special equipment to clean or maintain. By contrast, a wellarranged operation and maintenance plan may attract more occupants and ensure the successful pursuit and accomplishment of plans. Many researchers have argued that facility designers fail to utilize conservation devices that decrease the use of chemical cleaning products, thus cutting down on maintenance costs (Lehrer, 2001; Tladi, 2012). Therefore, the role of the FM manager should include crucial aspects of building management, such as checking for ease of cleaning and maintenance of building surroundings.

\subsection{Space Management}

Che'Mat and Shah (2006) defined the role of FM managers as guaranteeing a high rate of utilization during the design stage. In their review of organizations, Hodge et al. (2002) and Yu (2006) surmised that organizations should be flexible and focused on change. The current industrial situation has been portrayed as steady and simple, since the capacity to change and react to new environmental conditions is considered crucial for long-term survival. According to Che'Mat and Shah (2006), therefore, the role of the FM manager is to allow for the efficient flow of movement. For example, the FM manager should notify designers of any information regarding space, including information on room use, functional categories, shared use, room capacities, and room dimensions. They explain that the FM manager must ensure a high rate of utilization during the design stage (Che'Mat \& Shah, 2006).

Furthermore, Wan Hamdan et al. (2011) propose that information on space should be provided during the early stages of the design process to trigger a positive effect on FM and ensure pride in the facility in the context of higher education institutions. The FM process adheres to the National Higher Education Strategic Plan (NHESP), which requires investigation and early supervision in the development of infrastructure and resources to achieve optimum utilization. A high level of efficiency minimizes wastage in terms of building space, space capacity, tasks, actions, and occupancy. Space planning management can also support simultaneous demands on a workspace to expand business exercises and availability in the context of timing.

Fraser (2014) proposed that online fault detection and persistent observation on continuous monitoring condition $(\mathrm{CM})$ frameworks are becoming increasingly essential. This growing importance is largely due to the potential advantages of identifying component failures during 
their initial stages and preventing performance declines by ensuring adequate time to rectify faulty parts. In the long term, solid and stable CM frameworks can substitute for regular unit services through cost-cutting measures. $\mathrm{CM}$ is also a conscientious investment that supports the installation of hardware and software checking systems, as opposed to conventional checking systems (which are charged at cost for each observation). Thus, FM managers are required to provide information on integrated workplace management systems.

\subsection{Sustainability}

It has been conclusively shown that various roles are needed to engage and integrate sustainability into a VM study (Abidin \& Pasquire, 2007; Nawawi et. al, 2015). Abidin and Pasquire (2007) stated that FM managers should give input on sustainable development issues. However, concentrating too heavily on sustainable development may overshadow issues at the macro-scale level during the operational stage, since any design must have the capacity to minimize maintenance costs and ensure safety (Enoma, 2005). Including FM managers in the full scope of the design process may minimize costs in procurement accounts and reduce work modifications and unnecessary alterations (Enoma, 2005).

Nawawi et al. (2015) reported that the active participation of FM managers during preconstruction phases could ensure that sustainable strategies are not affected following the delivery of a facilities and that plans and policies for facilities are kept up-to-date. The FM manager's role in addressing sustainability includes checking for the appropriateness of various sustainability design aspects and offering input concerning waste disposal systems. Abidin and Pasquire (2005) found that respondents generally believe that sustainability issues are important and should be given attention in VM studies.

The use of new materials and technological advancements could help control energy wastage in the context of adding value to existing structures (Chan, 2014). New items can be expected to discharge low or no unpredictable organic compounds and formaldehydes, both of which can have negative ecological impacts and negative effects on building occupants. Poly Vinyl Chloride (PVC) utilization should be minimized through upgrades because of its negative effects relative to its life expectancy.

\subsection{Advantages of FM Involvement in a VM Study}

Utilizing FM as a rigorous approach for obtaining optimum values in a VM study has several benefits, including increased accessibility to various equipment for maintenance and replacements (Jawdeh, 2013), a better selection of equipment and materials (Jawdeh, 2013), a method of addressing sophistication and reducing complexity in modern buildings (Enoma, 2005; Tladi, 2012), and improved design output and increased design efficiency (Enoma, 2005, Tladi, 2012). Tladi (2012) believed that architects and/or civil engineers are responsible for deciding on materials and equipment based on availability. The materials selected must conform to certain criteria (e.g. non-hazardous, sustainable, and non-expensive), and these criteria should be standardized across the whole building (Jawdeh, 2013). Such measures may help boost the efficiency of FM. Furthermore, Jawdeh (2013) and Enema (2005) found that FM participation in the design stage may enable FM managers to achieve cost savings throughout a facility's life cycle. To avoid costly maintenance, service fees, and cleaning fees in the future, FM managers must engage in early preparation. In other words, FM participation in VM studies at an early stage could minimize the risks pertaining to workload and expenditure (Jawdeh, 2013).

\subsection{Disadvantages of FM Non-Involvement in a VM Study}

It is common knowledge that FM has drawn the attention of several organizations. Both the public and private sectors are highly satisfied with the implementation of FM practices in VM studies. However, FM non-involvement in the VM process has several disadvantages, including 
difficulties accessing equipment for maintenance purposes (Jawdeh, 2013), problems with electrical services and equipment (Jaunzens et al., 2001), problems with fixtures and fittings (Jaunzens et al., 2001), problems with the building fabric (Jaunzens et al., 2001), and problems with deliveries and waste management (Jaunzens et al., 2001). It is also possible to calculate a client's loss of profit due to the absence of FM in a VM study (Jawdeh, 2013). The abandonment of FM expertise within various business sectors may reduce designers' capability to fulfill clients' needs and produce more FM-efficient designs (Jawdeh, 2013). Furthermore, organizations may fail to consider life cycle costing analyses (Jaunzens et al., 2001). In other words, it may become meaningless to consider the total cost of life cycle accounting for all possible costs related to building construction and operation, particularly at their present values (Enoma, 2005).

\subsection{Latent Constructs of FM Functions in VM Study}

Throughout the literature review presented in this study, themes that support the continuation of this research to the next stage have been identified. The findings from the literature review demonstrate that there is a need to integrate FM into the role of FM managers in VM studies. Table 1 summarizes the indicators for seven latent constructs and 50 items gathered from the literature review, along with their sources.

Table 1 Indicators for latent construct

\begin{tabular}{|c|c|c|c|}
\hline Latent Construct & Indicators & Item Description & Source(s) \\
\hline \multirow[t]{7}{*}{$\begin{array}{l}\text { Client Satisfaction } \\
(\text { ClientS) }\end{array}$} & ClientS1 & $\begin{array}{l}\text { Coordinate with client to ensure that } \\
\text { all user and owner requirements are } \\
\text { included in the brief }\end{array}$ & $\begin{array}{l}\text { (Coenen \& Schäfer- } \\
\text { Cui, 2013; Jawdeh, } \\
\text { 2013; Hungu, 2013) }\end{array}$ \\
\hline & ClientS2 & $\begin{array}{l}\text { Assist in the preparation of the } \\
\text { project specifications }\end{array}$ & $\begin{array}{l}\text { (Elmualim et al., 2010; } \\
\text { Jensen et al., 2014) }\end{array}$ \\
\hline & ClientS3 & Answer questions posed by designers & (Jawdeh, 2013) \\
\hline & ClientS4 & $\begin{array}{l}\text { Ensure building design was carried } \\
\text { out to the expectations of facility } \\
\text { users }\end{array}$ & (Tladi, 2012) \\
\hline & ClientS5 & Finalize the brief for client signoff & $\begin{array}{l}\text { (Enoma, 2005; Jawdeh } \\
\text { et al., 2010; Tladi, } \\
\text { 2012; Jawdeh, 2013) }\end{array}$ \\
\hline & ClientS6 & $\begin{array}{l}\text { Provide POE outcomes to optimize } \\
\text { building performance }\end{array}$ & (Tladi, 2012) \\
\hline & ClientS7 & Provide inputs on SLAs & $\begin{array}{l}\text { (Koleoso et al., 2013; } \\
\text { Yasin, 2013; } \\
\text { Ikediashi, 2014) }\end{array}$ \\
\hline \multirow[t]{5}{*}{$\begin{array}{l}\text { Energy Efficiency } \\
\text { (EnerE) }\end{array}$} & EnerE1 & $\begin{array}{l}\text { Check for energy and resource } \\
\text { consumption (e.g. electricity, heating, } \\
\text { cooling, water) }\end{array}$ & $\begin{array}{l}\text { (Tladi, 2012; Hungu, } \\
\text { 2013; Tahir et al., } \\
\text { 2016) }\end{array}$ \\
\hline & EnerE2 & $\begin{array}{l}\text { Check for appropriateness of energy } \\
\text { saving }\end{array}$ & (Sheau et al., 2010) \\
\hline & EnerE3 & $\begin{array}{l}\text { Check for appropriateness of utility } \\
\text { services }\end{array}$ & $\begin{array}{l}\text { (Enoma, 2005; Tladi, } \\
\text { 2012) }\end{array}$ \\
\hline & EnerE4 & $\begin{array}{l}\text { Check for appropriateness of power } \\
\text { and water consumption }\end{array}$ & $\begin{array}{l}\text { (Tladi, 2012; Tahir et } \\
\text { al., 2016) }\end{array}$ \\
\hline & EnerE5 & Check for lighting aspects & $\begin{array}{l}\text { (Jawdeh et al., 2010; } \\
\text { Tahir et al., 2016) }\end{array}$ \\
\hline \multirow[t]{2}{*}{$\begin{array}{l}\text { Operation } \\
\text { Maintenance } \\
\text { (OpeM) }\end{array}$} & OpeM1 & $\begin{array}{l}\text { Provide technical information to help } \\
\text { designers produce the best design }\end{array}$ & $\begin{array}{l}\text { (Enoma, 2005; } \\
\text { Che'Mat \& Shah, } \\
\text { 2006) }\end{array}$ \\
\hline & OpeM2 & $\begin{array}{l}\text { Ensure that the FM requirements } \\
\text { stated in the brief are actually } \\
\text { reflected in the concept design }\end{array}$ & (Mustapa, 2013) \\
\hline
\end{tabular}




\begin{tabular}{|c|c|c|c|}
\hline Latent Construct & Indicators & Item Description & Source(s) \\
\hline & OpeM3 & $\begin{array}{l}\text { Apply life cycle costing in the } \\
\text { selection of materials and equipment }\end{array}$ & $\begin{array}{l}\text { (Tladi, 2012; } \\
\text { Hassanain et al., 2013; } \\
\text { Olanrewaju, 2013) }\end{array}$ \\
\hline & OpeM4 & $\begin{array}{l}\text { Ensure access to all areas inside the } \\
\text { building for maintenance work }\end{array}$ & (Mat et al., 2011) \\
\hline & OpeM5 & $\begin{array}{l}\text { Raise Operation and Maintenance } \\
\text { (O\&M) issues to avoid defects } \\
\text { during occupancy }\end{array}$ & (Tladi, 2012) \\
\hline & OpeM6 & $\begin{array}{l}\text { Assist in managing the selection of } \\
\text { materials and equipment to avoid } \\
\text { operational issues }\end{array}$ & (Jawdeh et al., 2010) \\
\hline & OpeM7 & $\begin{array}{l}\text { Ensure permanently elements designs } \\
\text { should be avoided in areas requiring } \\
\text { continuous maintenance work }\end{array}$ & (Enoma, 2005) \\
\hline & OpeM8 & $\begin{array}{l}\text { Check for ease of cleaning and } \\
\text { maintaining the building and } \\
\text { surrounding areas }\end{array}$ & (Tladi, 2012) \\
\hline \multirow[t]{5}{*}{$\begin{array}{l}\text { Space Management } \\
\text { (SpaceM) }\end{array}$} & SpaceM1 & $\begin{array}{l}\text { Ensure a design emphasis on efficient } \\
\text { and effective use of space }\end{array}$ & $\begin{array}{l}\text { (Che'Mat \& Shah; } \\
\text { 2006; Yu, 2006; } \\
\text { Ibrahim et al., 2012) }\end{array}$ \\
\hline & SpaceM2 & Ensure a high rate of utilization & $\begin{array}{l}\text { (Che'Mat \& Shah } \\
\text { 2006) }\end{array}$ \\
\hline & SpaceM3 & $\begin{array}{l}\text { Provide info on integrated workplace } \\
\text { management systems (CMMS) }\end{array}$ & (Fraser, 2014) \\
\hline & SpaceM4 & Give information on space needs & $\begin{array}{l}\text { (Wan-Hamdan et al., } \\
\text { 2011) }\end{array}$ \\
\hline & SpaceM5 & $\begin{array}{l}\text { Assist with general layout and } \\
\text { circulation }\end{array}$ & (Tladi, 2012) \\
\hline \multirow[t]{5}{*}{$\begin{array}{l}\text { Sustainability } \\
\text { (Sust) }\end{array}$} & Sust1 & $\begin{array}{l}\text { Check for appropriateness of } \\
\text { sustainability aspects }\end{array}$ & (Nawawi et al., 2015) \\
\hline & Sust2 & Give input on waste disposal system & (Price, 2012) \\
\hline & Sust3 & $\begin{array}{l}\text { Ensure the design considers } \\
\text { sustainability factors }\end{array}$ & $\begin{array}{l}\text { (Enoma, 2005; Nawi } \\
\text { et al., 2014) }\end{array}$ \\
\hline & Sust4 & $\begin{array}{l}\text { Avoid the design of non- } \\
\text { environmentally friendly systems }\end{array}$ & (Mcauley et al., 2015) \\
\hline & Sust5 & $\begin{array}{l}\text { Express preferences concerning } \\
\text { options for new products and discuss } \\
\text { their suitability }\end{array}$ & (Jensen et al., 2012) \\
\hline \multirow[t]{6}{*}{ Advantages (Adv) } & Adv1 & $\begin{array}{l}\text { Properly address client and FM } \\
\text { requirements to achieve satisfaction }\end{array}$ & $\begin{array}{l}\text { (Jensen, 2009; } \\
\text { Jawdeh, 2013) }\end{array}$ \\
\hline & Adv2 & $\begin{array}{l}\text { Address sophistication and } \\
\text { complexity reduction in modern } \\
\text { buildings }\end{array}$ & $\begin{array}{l}\text { (Enoma, 2005; Tladi, } \\
\text { 2012) }\end{array}$ \\
\hline & Adv3 & Improve design output and efficiency & $\begin{array}{l}\text { (Enoma, 2005; Tladi, } \\
\text { 2012) }\end{array}$ \\
\hline & Adv4 & $\begin{array}{l}\text { Minimize abortive work during } \\
\text { construction and operation }\end{array}$ & $\begin{array}{l}\text { (Enoma, 2005; Tladi, } \\
\text { 2012) }\end{array}$ \\
\hline & Adv5 & $\begin{array}{l}\text { Achieve cost savings throughout the } \\
\text { facilities life cycle }\end{array}$ & $\begin{array}{l}\text { (Enoma, 2005; } \\
\text { Jawdeh, 2013) }\end{array}$ \\
\hline & Adv6 & Ensure a smooth takeover of facilities & (Jensen, 2009) \\
\hline \multirow[t]{3}{*}{ Advantages (Adv) } & Adv7 & $\begin{array}{l}\text { Increase accessibility to various } \\
\text { equipment for maintenance and } \\
\text { replacements }\end{array}$ & (Jawdeh, 2013) \\
\hline & Adv8 & $\begin{array}{l}\text { Provide FM with knowledge about } \\
\text { systems early on }\end{array}$ & (Tladi, 2012) \\
\hline & Adv9 & Improve the selection of equipment & (Arditi \& \\
\hline
\end{tabular}




\begin{tabular}{|c|c|c|c|}
\hline & \multicolumn{2}{|r|}{ and materials } & \multirow{2}{*}{$\begin{array}{l}\text { Nawakorawit 1999; } \\
\text { Tladi 2012) } \\
\text { (Jensen, 2009) }\end{array}$} \\
\hline & Adv10 & $\begin{array}{l}\text { Reduce future operational } \\
\text { expenditures }\end{array}$ & \\
\hline \multirow[t]{10}{*}{$\begin{array}{l}\text { Disadvantages } \\
\text { (DisAdv) }\end{array}$} & DisAdv1 & $\begin{array}{l}\text { Wrong interpretations of FM } \\
\text { requirements by designers }\end{array}$ & $\begin{array}{l}\text { (Jawdeh, 2013; } \\
\text { Xianhai, 2013) }\end{array}$ \\
\hline & DisAdv2 & System inefficiencies & $\begin{array}{l}\text { (Jawdeh, 2013; } \\
\text { Xianhai, 2013) }\end{array}$ \\
\hline & DisAdv3 & Clients' loss of profit & (Jawdeh, 2013) \\
\hline & DisAdv4 & $\begin{array}{l}\text { Access difficulties for maintenance } \\
\text { purposes }\end{array}$ & $\begin{array}{l}\text { (Hassanain et al., } \\
\text { 2013) }\end{array}$ \\
\hline & DisAdv5 & $\begin{array}{l}\text { Cleaning difficulties (especially on } \\
\text { the external facade) }\end{array}$ & $\begin{array}{l}\text { (Jawdeh, 2013; } \\
\text { Xianhai, 2013) }\end{array}$ \\
\hline & DisAdv6 & $\begin{array}{l}\text { Failure to consider lifecycle costing } \\
\text { analysis }\end{array}$ & (Jaunzens et al., 2001) \\
\hline & DisAdv7 & $\begin{array}{l}\text { Problems with electrical services and } \\
\text { equipment }\end{array}$ & $\begin{array}{l}\text { (Jaunzens et al., 2001; } \\
\text { Xianhai, 2013) }\end{array}$ \\
\hline & DisAdv8 & Problems with fixtures and fittings & $\begin{array}{l}\text { (Jaunzens et al., 2001; } \\
\text { Xianhai, 2013) }\end{array}$ \\
\hline & DisAdv9 & Problems with the building fabric & (Jaunzens et al., 2001) \\
\hline & DisAdv10 & $\begin{array}{l}\text { Problems with deliveries and waste } \\
\text { management }\end{array}$ & (Jaunzens et al., 2001) \\
\hline
\end{tabular}

\section{CONCLUSION}

It can be assumed that studies on VM in Malaysia are as extensive as those conducted elsewhere. Generally, the use of VM in Malaysia yields the same improvements as implementations of VM frameworks globally, and such improvements have been incorporated into the concept of sustainability within construction projects. This integration should be adopted into the building management culture at an early stage in order to guarantee that project needs are achieved within the relevant project scopes.

In Malaysia, FM and VM have been evolved within several organizations for decades. Thus, it is possible to understand the practices of FM functions in the context of VM practices in Malaysia. To ensure better solutions and outputs and avoid future problems, both FM and VM should be applied throughout a building's whole life cycle, starting with the early design stages. The present study has endeavored to enhance our understanding of the importance of FM functions in a VM study. The authors hope that the combination of FM and VM will be helpful in increasing buildings' value and saving time, effort, and money.

More data and information on FM functions in VM studies would help us establish a greater degree of accuracy concerning our findings. If the debate is to move forward, better understandings of client satisfaction, energy efficiency, ergonomics, operation and maintenance, space management, and sustainability must be developed. These research gaps require further investigation on the benefits of FM involvement and the drawbacks of FM noninvolvement in VM studies.

\section{ACKNOWLEDGEMENT}

The authors wish to thank the funding bodies of this research, including, namely, the University of Malaya (FRGS Project No. FP025-2014B). We also thank the editor and anonymous reviewers for their comments, which were beneficial in improving this paper. 


\section{REFERENCES}

Abidin, N.Z., Pasquire, C.L., 2005. Delivering Sustainability through Value Management: Concept and Performance Overview. Engineering, Construction and Architectural Management, Volume 12(2), pp. 168-180

Abidin, N.Z., Pasquire, C.L., 2007. Revolutionize Value Management: A Mode Towards Sustainability. International Journal of Project Management, Volume 25(3), pp. 275-282

Arditi, D., Nawakorawit, M., 1999. Designing Buildings for Maintenance: Designers' Perspective. Journal of Architectural Engineering, Volume 5(4), pp. 107-116

Atkin, B., Björk, B., 2007. Understanding the Context for Best Practice Facilities Management from the Client's Perspective. Facilities, Volume 25(13/14), pp. 479-492

Chan, E., 2014. Building Maintenance Strategy: A Sustainable Refurbishment Perspective. Universal Journal of Management, Volume 2(1), pp. 19-25

Che'Mat, M.M., Shah, Z.M., 2006. Value Management as an Effective and Efficient Tool for Space Management. Available online at http://www.vmacademy.com/seminar_paper_01.pdf

Cloete, C.E., 2002. Introduction to Facilities Management. Sandton: South African Property Education Trust

Coenen, C., Schäfer-Cui, Y.Y., 2013. Relationship Value in FM: A Customer Perspective. EFMC2013, Volume 9-24, pp. 1-18

Elmualim, A., Shockley. D., Valle. R., Ludlow, G., \& Shah. S., 2010. Barriers and Commitment of Facilities Management Profession to the Sustainability Agenda. Building and Environment, Volume 45(1), pp. 58-64

Enoma, A., 2005. The Role of Facilities Management at the Design Stage, in Khosrowshahi, F. (ed.), $21^{\text {st }}$ Annual ARCOM Conference, 7-9 September 2005, SOAS, University of London. Association of Researchers in Construction Management, London, Volume 1, pp. 421-430

Erdener, E., 2003. Linking Programming and Design with Facilities Management. Journal of Performance of Constructed Facilities, Volume 17(1), pp. 4-8

Fraser, K., 2014. Facilities Management: The Strategic Selection of a Maintenance System. Journal of Facilities Management, Volume 12(1), pp. 18-37

Hartungi, R., Jiang, L., 2012. Energy Efficiency and Conservation in an Office Building: A Case Study. International Journal of Energy Sector Management, Volume 6(2), pp. 175188

Hassanain, M.A., Assaf, S., Al-Ofi, K., Al-Abdullah, A., 2013. Factors Affecting Maintenance Cost of Hospital Facilities in Saudi Arabia. Property Management, Volume 31(4), pp. 297 310

Hodge, B.J., William, P.A., Gales, L.M., 2002. Organization Theory: A Strategic Approach $\left(6^{\text {th }}\right.$ Ed). New Jersey, U.S.: Prentice Hall

Hungu, C.F., 2013. Utilization of BIM from Early Design Stage to Facilitate Efficient FM Operations. Master's Thesis. Chalmers University of Technology, Göteborg, Sweden

Ibrahim, I., Yusoff, W.Z.W., Bilal, K., 2012. Space Management: A Study on Space Usage Level in Higher Education Institutions. Procedia-Social and Behavioral Sciences, Volume 47, pp. 1880-1887

Ikediashi, D.I., 2014. A Framework for Outsourcing Facilities Management Services in Nigeria's Public Hospitals. Ph.D. Thesis. School of the Built Environment, Heriot-Watt University, Edinburgh, United Kingdom

Jaunzens, D. Warriner, D., Garner, U. \& Waterman, A., 2001. Applying Facilities Expertise in Building Design. Bracknell, United Kingdom: Ihs Bre Press

Jawdeh, H.B., 2013. Improving the Integration of Building Design and Facilities Management. University of Salford, Salford, UK. 
Jawdeh, H.B., Wood, G., Abdul-Malak, M.A., 2010. Altering Design Decisions to Better Suit Facilities Management Processes, In: Tenth International Conference for Enhanced Building Operations, Kuwait, October 26-28, 2010, pp. 1-7

Jensen, P.A., 2009. Design Integration of Facilities Management: A Challenge of Knowledge Transfer. Architectural, Engineering and Design Management, Volume 5(3), pp. 124-135

Jensen, P.A., Voordt, T.V.D., Coenan, C., Felten, D.V., Lindholm, A.L., Nielsen, S.B.,

Rirathanaphong, C. \& Pfenninger, M., 2012. In Search for the Added Value of FM: What We Know and What We Need To Learn. Facilities, Volume 30(5/6), pp. 199-217

Jensen, P.A., Voordt, T.V.D., Coenan, C. \& Sarasoja, A.L., 2014. Reflecting on Future Research Concerning the Added Value of FM. Facilities, Volume 32(13/14), pp. 856-870

Kamaruzzaman, S.N., Zawawi, E.M.A., 2010. Development of Facilities Management in Malaysia. Journal of Facilities Management, Volume 8(1), pp. 75-81

Kelly, J., Hunter, K., Shen, G. \& Yu, A., 2005. Briefing from a Facilities Management Perspective. Facilities, Volume 23(7-8), pp. 356-367

Koleoso, H., Omirin, M., Adewunmi, Y. \& Babawale, G., 2013. Applicability of Existing Performance Evaluation Tools and Concepts to the Nigerian Facilities Management Practice. International Journal of Strategic Property Management, Volume 17(4), pp. 361376

Lehrer, D. 2001. Sustainable Design, in Teicholz, E. (Ed.), Facility Design and Management Handbook. New York, NY: McGraw-Hill.

Mat, N.E.M.N., Kamaruzzaman, S.N., Pitt, M., 2011. Assessing the Maintenance Aspect of Facilities Management through a Performance Measurement System: A Malaysian Case Study. Procedia Engineering, Volume 20, pp. 329-338

McAuley, B., Hore, A. \& West, R., 2015. The Development of Key Performance Indicators to Monitor Early Facilities Management Performance through the Use of BIM Technologies in Public Sector Projects, In: Proceedings of the $2^{\text {nd }}$ Proceedings International Conference on Civil and Building Engineering Informatics, April 23-25, Tokyo, Japan, pp. 1-8

Mustapa, M., 2013. Facilities Management Knowledge in Private Finance Initiative (PFI) Healthcare Projects. Loughborough University. Available online at https://dspace.lboro.ac.uk/dspace-jspui/bitstream/2134/12843/4/Thesis-2013-Mustapa.pdf.

Nawawi, A.H., Muhammad, F., Mahbub, R. \& Zainul-Abidin, N., 2015. Perceived Project Sustainability Performance Indicators (PPSPI) for Value Planning. Procedia-Social and Behavioral Sciences, Volume 202, pp. 89-97

Nawi, M.N.M., Radzuan, K., Salleh, N.A. \& Ibrahim S.H., 2014. Value Management: A Strategic Approach for Reducing Faulty Design and Maintainability Issue in IBS Building. Advances in Environmental Biology, Volume 8(5), pp. 1859-1863

Olanrewaju, A.L.A., 2013. A Critical Review of Value Management and Whole Life Costing on Construction Projects. International Journal of Facility Management, Volume 4(1), pp. $1-12$

Preiser, W.F.E., 2003. Continuous Quality Improvement through Post-Occupancy Evaluation Feedback. Journal of Corporate Real Estate, Volume 5(1), pp. 42-56

Price, S., 2012. To Deliver a Sustainable Built Estate: The Management and Operationalisation of Sustainable Facilities Management. London, UK: UCL (University College London)

Sheau, T.L., Mohamed, A.H., Weng, W.C. \& Alias, B., 2010. Facilities Management: Paths of Malaysia to Achieve Energy Sustainability. International Journal of Facility Management, Volume 1(2), pp. 1-10

Talib, Y.A., 2013. Strategic Facilities Management for Australian Public Healthcare Operation. Ph.D. Thesis, School of Architecture and Built Environment, Deakin University, Australia

Tahir, M.Z., Nawi, M.N.M., Rajemi, M.F., 2016. The Potential of Value Management (VM) to Improve the Consideration of Energy Efficiency within Pre-Construction. In: International 
Conference on Applied Science and Technology 2016 (ICAST'16), AIP Conference Proceedings, Volume 1761(1), pp. 020102-1-020102-6

Tladi, K., 2012. Evaluating the Facility Manager's Role in Project Design. Johannesburg: University of the Witwatersrand.

Wan-Hamdan, W.S.Z., Hamid, M.Y., Mohd-Radzuan, N.A., 2011. Contribution of Facilities Management Processes in Supporting Malaysia National Higher Education Strategic Plan. Procedia Engineering, Volume 20, pp. 180-187

Wang, Y., Wang, X., Wang, J., Yung, P. \& Jun, G., 2013. Engagement of Facilities Management in Design Stage through BIM: Framework and a Case Study. Advances in Civil Engineering, Volume 2013, pp. 1-8

Way, M., 2006. Soft Landings: A Fresh Scope of Service that Ensures Users and Clients Get the Best Out of a New Building. Journal of Facilities Management, Volume 4(1), pp. 2339

Xianhai, M., 2013. Involvement of Facilities Management Specialists in Building Design: United Kingdom Experience. Journal of Performance of Constructed Facilities, Volume 27(5), pp. 500-507

Yasin, M.F.M., 2013. The Contributions of Knowledge Mapping in Facilities Performance Evaluation Practice in Malaysia. Salford, UK: University of Salford

Yu, T.A., 2006. A Value Management Framework for Systematic Identification and Precise Representation of Client Requirements in the Briefing Process. Hong Kong: The Hong Kong Polytechnic University. Available online at http://hdl.handle.net/10397/2788 